\title{
SPECYFIKA PRZYWÓDZTWA EDUKACYJNEGO - KIEROWANIE GRONEM PEDAGOGICZNYM
}

\section{Abstract \\ The specificity of Educational Leadership — leading teachers}

Educational leadership undoubtedly influences the quality of the processes occurring in educational institutions. How it is understood can impact actions taken by school heads and these actions may be completely different. The aim of this study is to present the ways of thinking and interpreting leadership styles of a group of Polish school heads. In the course of the analyses of differences in ways of understanding leadership, a classification by Gayle Avery [2009], distinguishing classical, transactional, visionary and organic leadership, was used.

Keywords: leadership, educational leadership, teachers

\section{Streszczenie}

Przywództwo edukacyjne bez wątpienia wpływa na jakość procesów zachodzących w placówkach oświatowych. Sposób jego rozumienia wpływa na działania podejmowane przez dyrektorów, które mogą być skrajnie różne. Celem niniejszego opracowania jest przedstawienie sposobu myślenia i interpretowania stylów przywództwa przez grupę dyrektorów polskich szkół. W toku analizy różnic w sposobach rozumienia przywództwa zastosowano klasyfikację zaproponowaną przez Gayle Avery [2009], która wyróżnia przywództwo klasyczne, transakcyjne, wizjonerskie i organiczne.

Słowa kluczowe: przywództwo, przywództwo edukacyjne, grono pedagogiczne

\section{Wprowadzenie}

Wieloletnie działania podejmowane w kierunku doskonalenia sytemu oświaty w Polsce wpływają na prowadzenie dialogu społecznego. Wielu zwolenników, jak i przeciwników reform oświatowych dzieli się poglądami i przekonaniami, argumentując słuszność ideologii, filozofii oraz doktryn prawidłowego funkcjonowania szkolnictwa. Podejmowane działania zależne są od wewnętrznych 
przekonań, wartości i postaw, które zakorzenione są w mentalności społecznej i uwzględniają zasady zawarte w Konstytucji Rzeczpospolitej Polskiej. Osoby czy też organizacje odpowiedzialne za wprowadzanie zmian w systemie oświatowym kierują się dobrem publicznym powszechnie akceptowanym, zawartym zarówno w Konwencji o Prawach Dziecka, jak i w Powszechnej Deklaracji Praw Człowieka oraz w Międzynarodowym Pakcie Praw Obywatelskich i Politycznych [UoSO, 1991]. Wielokrotnie podczas powszechnie prowadzonego dialogu dotyczącego jakości funkcjonowania placówek oświatowych pojawia się kluczowa rola nauczycieli powoływanych na stanowisko dyrektorów. Sformułowane wymagania, odwołujące się do kandydatów na stanowisko kierownicze, dotyczą wykształcenia wyższego, stażu pracy, doświadczenia, zdrowia fizycznego i psychicznego, zdolności do czynności prawnych oraz braku karalności dyscyplinarnej [UoSO, 1991]. Oczywiście nie są to wszystkie wymagania stawiane potencjalnym dyrektorom szkół. Specyfika powoływania nauczycieli na dyrektorów w drodze konkursu polega na tym, że nie ma jasnych i klarownych wytycznych [Mazurkiewicz, 2011; Dorczak, 2015a], czy dany kandydat poradzi sobie ze złożonością zadań przy ograniczonych finansach [Stoner, Wankel, 1996].

\section{Rola szkoły}

Umiejętne dostrzeganie, rozpoznawanie i nazywanie zachodzących zmian umożliwia właściwe poznawanie świata. To z kolei prowadzi do sformułowania zagadnień podejmowanych $\mathrm{w}$ procesie uczenia się, za który odpowiedzialna jest szkoła [Mazurkiewicz, 2011; Senge, 2012]. Respektując zasady zapisane w aktach prawnych, polska oświata dąży do kształcenia i wychowania młodego pokolenia w taki sposób, aby odpowiedzialność, solidarność, poszanowanie oraz otwartość na wartości innych narodów stały się priorytetem. Ważne jest, aby placówki oświatowe dostosowywały się do możliwości psychofizycznych uczniów, dobierając odpowiednie metody, formy i treści. Celem polskiego szkolnictwa jest zapewnienie zajęć edukacyjnych, nauki języka nowożytnego, zajęć psychologiczno-pedagogicznych, rewalidacyjnych dla uczniów z niepełnosprawnością oraz zajęć, podczas których uczniowie mogą rozwijać swoje zainteresowania. Wymienione działania zobowiązany jest zorganizować dyrektor szkoły za zgodą organu prowadzącego i po zasięgnięciu opinii rady pedagogicznej i rady rodziców [UoSO, 1991].

Obecna reforma oświatowa spowodowała, że z jednej strony dyrektorzy koncentrują się na rozwoju dzieci i młodzieży, a z drugiej nieustannie dostosowują się do nowych wymagań związanych z technicznym wyposażeniem szkół [Mazurkiewicz, 2012; Dorczak, Hesse-Gawęda, 2016b]. Ważnym aspektem funkcjonowania szkolnictwa jest wspomaganie rodzin w procesie wychowawczym, tworzenie programów indywidualnych dla dzieci uzdolnionych i dla tych, które mają trudności edukacyjne. Istotne jest zapewnienie opieki dzieciom z trudnościami finansowymi oraz umiejętne przygotowanie ich do wejścia na rynek pracy w taki sposób, aby potrafiły poradzić sobie w sytuacjach trudnych i stresujących. Niskie 
subwencje oświatowe mogą prowadzić do braku stabilności finansowej placówek oświatowych. Warto wspomnieć, że wszystkie osoby, które związane są ze szkołą, pośrednio lub bezpośrednio odpowiadają za proces kształcenia, a w szerszym rozumowaniu odpowiadają za jakość funkcjonowania przyszłego społeczeństwa [Mazurkiewicz, 2011].

\section{Działania dyrektora szkoły}

Każda osoba, której w drodze konkursu organ prowadzący powierzy stanowisko dyrektora szkoły, zobowiązana jest do sprawowania nadzoru pedagogicznego oraz kierowania działalnością placówki przy współpracy z radą pedagogiczną, radą rodziców i środowiskiem lokalnym. Aktywność ta polega na podejmowaniu i realizowaniu uchwał oraz dysponowaniu środkami finansowymi w taki sposób, w jaki zaopiniowali to nauczyciele i rodzice. Dyrektor odpowiada również za zatrudnianie, zwalnianie nauczycieli i pracowników cywilnych oraz przyznawanie nagród i kar porządkowych. Jednak wszystko, co czyni, wynika z wewnętrznego przekonania i wizji modelu dobrze funkcjonującego dyrektora [Mazurkiewicz, 2012; Dorczak, Hesse-Gawęda, 2016a]. Subiektywna opinia może doprowadzić do narcystycznych postaw, które nie sprzyjają rozwijaniu organizacji szkolnych.

W każdej placówce oświatowej kolegialnym organem realizującym zadania wynikające ze statutu jest rada pedagogiczna. Powoływana jest wówczas, kiedy placówka zatrudnia minimum trzech nauczycieli. Działania jej skupiają się w obrębie kształcenia, wychowania i opieki nad uczniami. Przewodniczącym rady pedagogicznej jest dyrektor szkoły, a członkami są wszyscy nauczyciele zatrudnieni w placówce. Uchwały podejmowane są większością głosów, a każde zebranie rady pedagogicznej jest protokołowane. Rada pedagogiczna zatwierdza plany pracy szkoły, podejmuje uchwały dotyczące klasyfikacji i promocji uczniów, wprowadza innowacje i eksperymenty pedagogiczne, ustala organizację doskonalenia zawodowego nauczycieli oraz opiniuje wnioski, organizację i propozycje dyrektora szkoły [UoSO, 1991].

Specyfika przywództwa edukacyjnego, a w nim kierowanie radą pedagogiczną, polega na umiejętnym realizowaniu wszystkich wymagań państwa względem placówek oświatowych. Ważne jest tworzenie przestrzeni do wspólnego dialogu, podczas którego przywódcy potrafią słuchać i wspólnie z pracownikami podejmować decyzje [Mazurkiewicz, 2015]. Aby zgłębić tematykę współpracy pracodawcy z osobami zatrudnianymi, warto zastanowić się nad stylami przywództwa reprezentowanymi przez dyrektora szkoły. Gayle Avery [2009] zaproponowała cztery paradygmaty zarządzania: klasyczny, transakcyjny, wizjonerski i organiczny, które nie są odrębnymi stylami, ale wzajemnie się przenikają [Avery, 2009: 38]. Każdy z tych stylów odnosi się do decyzji podejmowanych przez dyrektora w drodze codziennego funkcjonowania placówki. Należy podkreślić, że w 2012 roku Grzegorz Mazurkiewicz opublikował wyniki swoich badań prowadzonych wśród dyrektorów polskich szkół, dotyczące określenia świadomości rozumienia i definiowania koncepcji przywódczych zaproponowanych przez Avery. Przedstawione 
wyniki ukazały różnorodność podejmowanych zadań wynikających ze sposobu myślenia na temat znaczenia, jakie ma pełnienie funkcji dyrektora szkoły [Mazurkiewicz, 2012].

Pierwszy z nich to styl przywództwa klasycznego, który dominował przede wszystkim w XX wieku. Polega on na dominacji jednej osoby lub grupy osób nad innymi. Bezwzględne podporządkowanie się dyrektorowi wprowadzane przez strach, niepokój, lęk służy realizacji określonych celów, które nie muszą być jasno wyartykułowane. Ścisły podział na władcę i podwładnych wytwarza bezwzględne posłuszeństwo wydawanym dyrektywom, które nie podlegają otwartej krytyce. Wszelkie nieposłuszeństwo może być piętnowane i karane. Choć mamy już XXI wiek, przywództwo klasyczne nadal jest spotykane w organizacjach szkolnych. Może wynikać to z błędnego rozumowania, że przywódca przez swój status materialny, bożą posługę, pozycję gospodarczą ma prawo dyktować innym, co należy robić. Oczywiście działanie to może okazać się wygodne dla tych, którzy wykonują określone polecenia, ponieważ wszelka odpowiedzialność zostaje przeniesiona na przywódcę [Avery, 2009: 39-41].

Drugim opisywanym stylem jest przywództwo transakcyjne, w którym lider oraz członkowie grupy komunikują się ze sobą, uwzględniając umiejętności, potrzeby oraz motywy działania. Przywódca umożliwia swojemu zespołowi rozwijanie się, przy czym niejednokrotnie dyskutuje, negocjuje i wykorzystuje swój wpływ, aby osiągnąć określony cel [Avery, 2009: 42-44]. Podejmowany dialog pomaga podwładnym nabrać pewności co do celowości podejmowanego wysiłku [Stoner, Wankel, 1996]. Członkowie zespołu postrzegają swojego przywódcę jako osobę, która ma pewne istotne kompetencje oraz wiedzę w danym zakresie sprzyjającą osiąganiu celów. Jednak powszechnie wiadomo, że przywódca jest nadal osobą decydującą [Avery, 2009: 44]. Jak wynika z badań prowadzonych przez Grzegorza Mazurkiewicza, w 2012 roku zaledwie 6\% respondentów reprezentowało styl przywództwa transakcyjnego [Mazurkiewicz, 2012]. Cztery lata później, w badaniach prowadzonych przez Romana Dorczaka i Annę Hesse-Gawędę [2016a], styl przywództwa transakcyjnego w opinii dyrektorów szkół wystąpił częściej. Wśród 70 badanych dyrektorów szkół różnego typu aż 17 osób $(24,28 \%)$ wskazywało, że reprezentuje styl przywództwa transakcyjnego. Nie zmienia to faktu, że styl ten może być odpowiedni, ale tylko w okresie stabilizacji lub powolnych zmian [Avery, 2009: 42].

Kolejnym paradygmatem jest przywództwo wizjonerskie, które pojawiło się w XX wieku. Stanowiło odpowiedź na umiejętne radzenie sobie w czasach szybkich i nieprzewidywalnych zmian. Zamiennie styl przywództwa wizjonerskiego nazywano charyzmatycznym, transformacyjnym, inspiracyjnym. W tym paradygmacie przywódcy jasno określają wizję przyszłości organizacji, której przewodzą. Potrafią zaplanować i zmotywować wszystkich członków zespołu do realizacji określonych zadań [Avery, 2009: 44-45]. Przywódca zachęca podwładnych do podejmowania większego wysiłku, niż pierwotnie został założony [Stoner, Wankel, 1996]. Prawidłowo zakreślona wizja wyraża marzenia i pragnienia pracowników. Dyrektor niejednokrotnie odwołuje się do wewnętrznych uczuć pracowników w celu wpływania na rozwój i zaangażowanie w dążeniu do określonego celu [Blanchard, 
2016]. Wizje mogą wypływać od pracowników oraz mogą być wypracowywane wspólnie przy pełnej akceptacji przywódcy. Pomimo wielu pozytywnych opinii przywództwo wizjonerskie posiada wadę. W sytuacji, kiedy w organizacji znajdą się osoby, które nie podzielają zdania przywódcy, najczęściej są one zmuszone do opuszczenia zespołu [Avery, 2009: 47]. Bezkrytyczna adoracja wizjonera oraz utwierdzanie go w nieomylności tworzy złudny obraz pożądanego przywództwa edukacyjnego [Yukl, 2014]. Należy wspomnieć, że skuteczni przywódcy wcale nie muszą być wizjonerami [Collins, 2001].

Ostatnim stylem przywództwa jest przywództwo organiczne. Przez wiele lat uważano, że jedność w zespole oraz wspólna wizja prowadzą do sukcesu. Po 2000 roku przekonanie to zaczęło nabierać zupełnie innego znaczenia. Postępujący proces globalizacji oraz wielokulturowość organizacji sprawiają, że władza skoncentrowana na jednej osobie ulega rozproszeniu. Rozwiązywanie problemów wymaga spojrzenia z różnych perspektyw, włączając wiedzę, kwalifikacje oraz talenty wszystkich członków tworzących organizację. Rolą przywódcy jest zachęcanie do pracy, podsycanie entuzjazmu, koordynowanie i wspieranie w działaniach podejmowanych przez zespół. Celem jest godzenie odmiennych poglądów i szukanie wspólnych rozwiązań co do roli przywódcy oraz wizji funkcjonowania organizacji. Działanie to wynika z wciąż rosnącej różnorodności kompetencji oraz świadomości, że nie ma jednego dobrego rozwiązania. Dochodzi tu do rozmycia podziału na przywódcę i podwładnych [Avery, 2009: 47-48]. Paradygmat ten proponuje koncepcję dyskretnego przywódcy (cover leadership). Polega ona na włączaniu wszystkich członków organizacji, którzy mają inicjatywę i pomysły. Podejmując działania, stają się przywódcami [Mintzberg, 1998]. Skuteczni kierownicy bardzo rzadko wykorzystują swoje możliwości formalne płynące z zajmowanego stanowisko, aby wpłynąć na zespół. Stosują metody dążenia do wspólnych celów poprzez dialog, pochlebstwa i przykłady [Stoner, Wankel, 1996]. Powołując się ponownie na badania prowadzone przez Romana Dorczaka i Annę Hesse-Gawędę [2016a] - styl przywództwa organicznego w opinii dyrektorów badanych polskich szkół jest dominujący. Wśród 70 dyrektorów szkół różnego typu aż 47 reprezentuje styl przywództwa organicznego. Zatem więcej niż połowa - bo aż $67,14 \%$ - badanych uważa, że włączanie wszystkich osób tworzących społeczność szkolną stanowi sukces w osiąganiu celów [Dorczak, Hesse-Gawęda, 2016: 453].

James Stoner i Charles Wankel [1996] zwrócili uwagę na elastyczność poruszania się pomiędzy stylami przywództwa. Umożliwia to właściwe reagowanie na działania innych osób lub sytuacji oraz szybkie wprowadzanie zmian. Znajomość różnych stylów przywództwa pomaga w codziennym funkcjonowaniu placówek oświatowych [Stoner, Wankel, 1996: 400-401]. Ważne jest dostosowywanie stylu przywództwa do etapu rozwoju organizacji, a rolą lidera jest wykonywanie wszystkiego tego, czego w danym momencie nie potrafią wykonać osoby, którym się przewodzi [Blanchard, 2016]. 


\section{Metody badań}

Przywództwo edukacyjne w ostatniej dekadzie jest najbardziej akcentowaną wartością myślenia dotyczącego kierowania szkołą [Dorczak, 2015a]. Każdy $\mathrm{z}$ dyrektorów placówki oświatowej w codziennym funkcjonowaniu kieruje się określonym stylem przywództwa. Można założyć, że w zależności od tego, jak rozumie funkcję bycia dyrektorem, podejmuje on decyzje, które wpływają na jakość zachodzących procesów. Refleksja nad tym, jakim chce być przywódcą, odgrywa dużą rolę. Działanie to wpływa na chęć poznawania pożądanych i akceptowanych cech przywódczych oraz właściwy dobór działań, które prowadzą do osiągania określonych rezultatów [Madalińska-Michalak, 2007]. Wolność, równość i sprawiedliwość społeczna, szacunek i zaufanie to nieliczne wartości, dzięki którym wspólnie podejmowany wysiłek i trud włożony w proces przywódczy uczenia się i nauczania może prowadzić do sukcesu [Dorczak, 2015b].

W maju 2017 roku w Krakowie odbyła się ogólnopolska konferencja zorganizowana dla dyrektorów placówek oświatowych mieszczących się na terenie Polski. Chęć udziału w badaniu wyraziło 37 dyrektorów szkół. Zadaniem respondentów było zdefiniowanie rodzajów przywództwa zaproponowanych przez Gayle Avery [2009]. Badanie zostało poprzedzone wykładem wyjaśniającym, na czym polegają oraz czym się charakteryzują poszczególny style, bez oceniania ich. Dyrektorzy różnych typów szkół zostali podzielenie na cztery grupy. Trzy grupy liczyły po 9 osób, jedna grupa liczyła 10 osób. Każdy z dyrektorów samodzielnie interpretował słuszność bądź też brak przychylności względem określonych działań w obszarze poszczególnych stylów przywódczych.

\section{Wyniki badań}

Grupa 37 dyrektorów, jak już wcześniej wspomniano, została podzielona na 4 zespoły. Każdy z nich miał za zadanie opracować pozytywne i negatywne skutki stosowania przywództwa klasycznego (10 osób), transakcyjnego (9 osób), wizjonerskiego ( 9 osób) i organicznego ( 9 osób) podczas codziennych czynności wykonywanych na rzecz funkcjonowania szkół, w których pracują. Uczestnicy badania przedstawili argumenty dotyczące określonego stylu przywództwa, które zostały usystematyzowane i przydzielone do określonej kategorii. Poniższe tabele przedstawiają wyniki prowadzonych badań.

Analizując wyniki badań dotyczące przywództwa klasycznego, można wnioskować, że pozytywnymi aspektami według wszystkich respondentów jest kontrola funkcjonowania placówki, w której pracują. Według połowy badanych ważne jest, aby przepływ informacji był jednostkowy, co według, dziewięciu osób spośród dziesięciu badanych prowadzi do podejmowania szybkich decyzji. Ośmiu dyrektorów ze swoich zadań wywiązuje się terminowo, a siedmiu z dziesięciu badanych zawsze pozostaje bezkrytycznych względem siebie. 
Tabela 1

Analiza przywództwa klasycznego - grupa 1

\begin{tabular}{|c|c|c|c|c|}
\hline $\begin{array}{c}\text { Rodzaj } \\
\text { przywództwa }\end{array}$ & \multicolumn{4}{|c|}{ Aspekt } \\
\hline \multirow{8}{*}{ 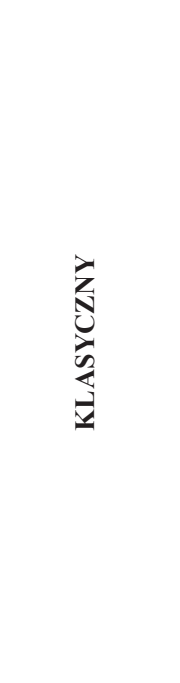 } & pozytywny & $\mathbf{n}$ & negatywny & n \\
\hline & $\begin{array}{l}\text { kontrola nad } \\
\text { funkcjonowaniem }\end{array}$ & 10 & $\begin{array}{l}\text { brak obiektywizmu w oce- } \\
\text { nianiu mocnych i słabych } \\
\text { stron szkoły }\end{array}$ & 6 \\
\hline & terminowość & 8 & zabijanie kreatywności & 4 \\
\hline & $\begin{array}{l}\text { decyzyjność/szybkie } \\
\text { reagowanie }\end{array}$ & 9 & $\begin{array}{l}\text { brak identyfikacji z real- } \\
\text { izowanymi zadaniami }\end{array}$ & 5 \\
\hline & $\begin{array}{l}\text { szybki przepływ informacji } \\
\text { (jednostkowy) }\end{array}$ & 5 & $\begin{array}{l}\text { niechęć do wykonywanych } \\
\text { zadań, niska ich jakość }\end{array}$ & 7 \\
\hline & $\begin{array}{l}\text { bezkrytyczność w stosun- } \\
\text { ku do siebie }\end{array}$ & 7 & zagrożenie mobbingiem & 2 \\
\hline & \multirow{2}{*}{\multicolumn{2}{|c|}{ - }} & $\begin{array}{l}\text { brak możliwości } \\
\text { współpracy } \\
\text { w zespole }\end{array}$ & 5 \\
\hline & & & $\begin{array}{l}\text { brak możliwości negocjacji } \\
\text { i wyboru }\end{array}$ & 6 \\
\hline
\end{tabular}

Źródło: opracowanie własne.

Negatywnymi aspektami stylu przywództwa klasycznego wskazywanymi przez sześciu badanych jest brak obiektywizmu w określeniu mocnych i słabych storn szkoły. Według połowy badanych niedostatek identyfikacji z placówką bezpośrednio wpływa na zabijanie kreatywności, co wskazało czterech dyrektorów, oraz według siedmiu osób wywołuje niechęć do wykonywanych zadań. Wszelkie inicjatywy mają niską wartość społeczną ze względu na ograniczoną możliwość pracy w zespole, co wskazało pięciu badanych. Negatywnym aspektem stosowanego przywództwa klasycznego według sześciu osób jest brak negocjacji oraz wyboru. Dwóch badanych wskazało również na możliwość wystąpienia mobbingu.

Dokonując analizy danych dotyczących stylu przywództwa transakcyjnego, można wnioskować, że pozytywnym aspektem wskazanym przez sześciu z dziewięciu badanych jest chęć podejmowania rozmowy przez dyrektora szkoły z pracownikami, natomiast siedmiu badanych wskazało zbieranie opinii i konsultowanie decyzje. Wszyscy respondenci uważają, że styl przywództwa transakcyjnego jasno określa cele i w sytuacjach kryzysowych dyrektor samodzielnie podejmuje decyzje. 
Analiza przywództwa transakcyjnego - grupa 2

\begin{tabular}{|c|c|c|c|c|}
\hline Rodzaj & \multicolumn{4}{|c|}{ Aspekt } \\
\hline \multirow{6}{*}{ 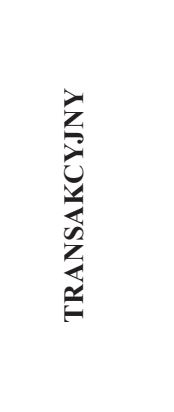 } & pozytywny & $\mathbf{n}$ & negatywny & $\mathbf{n}$ \\
\hline & $\begin{array}{l}\text { dyrektor podejmuje } \\
\text { rozmowę }\end{array}$ & 6 & $\begin{array}{l}\text { „złudzenie demokracji” } \\
\text { - nie każda propozycja } \\
\text { będzie realizowana }\end{array}$ & 9 \\
\hline & zbiera opinie & 7 & brak partnerstwa & 6 \\
\hline & konsultowanie decyzji & 7 & $\begin{array}{l}\text { silnie zarysowana } \\
\text { hierarchia }\end{array}$ & 8 \\
\hline & $\begin{array}{l}\text { zawsze podejmuje decyzje } \\
\text { w sytuacjach kryzysowych }\end{array}$ & 9 & hamuje rozwój & 4 \\
\hline & jasno określa role & 9 & \multicolumn{2}{|l|}{ - } \\
\hline
\end{tabular}

Źródło: opracowanie własne.

Negatywnymi skutkami przywództwa transakcyjnego jest tzw. złudna demokracja, co zostało wskazane przez wszystkich badanych. Nadal przez silnie zarysowaną hierarchię, na co zwróciło uwagę osiem osób, brakuje partnerstwa (wskazane przez sześciu badanych), a to z kolei wpływa na zahamowanie rozwoju placówki, co zostało podkreślone przez czterech uczestników badania.

Tabela 3

Analiza przywództwa wizjonerskiego - grupa 3

\begin{tabular}{|c|c|c|c|c|}
\hline Rodzaj & \multicolumn{4}{|c|}{ Aspekt } \\
\hline \multirow{8}{*}{ 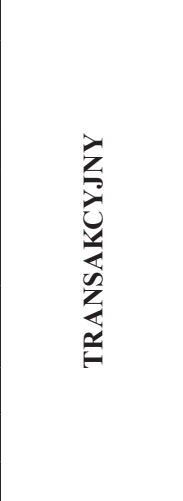 } & pozytywny & $\mathbf{n}$ & negatywny & n \\
\hline & $\begin{array}{l}\text { charyzmatyczny - może } \\
\text { zmieniać oblicze szkoły }\end{array}$ & 9 & $\begin{array}{l}\text { brak partnerstwa i umiejęt- } \\
\text { ności pracy w zespole }\end{array}$ & 7 \\
\hline & angażuje do pracy & 9 & niewykorzystany potencjał & 8 \\
\hline & unikanie chaosu & 8 & $\begin{array}{l}\text { zahamowanie rozwoju } \\
\text { szkoły } \\
\text { i nauczyciela }\end{array}$ & 6 \\
\hline & $\begin{array}{l}\text { wszyscy realizują daną } \\
\text { wizję }\end{array}$ & 9 & $\begin{array}{l}\text { sytuacja sprzyja } \\
\text { konfliktom }\end{array}$ & 5 \\
\hline & \multirow{3}{*}{\multicolumn{2}{|c|}{-}} & wypalenie zawodowe & 3 \\
\hline & & & brak obiektywizmu & 6 \\
\hline & & & zbyt wiele obowiązków & 2 \\
\hline
\end{tabular}

Źródło: opracowanie własne. 
Dziewięciu badanych dyrektorów wskazało, że pozytywnymi działaniami w przywództwie wizjonerskim jest możliwość dokonania zmiany oblicza szkoły w wyniku angażowania innych do pracy. Według dziewięciu respondentów ważne jest realizowanie jednolitej wizji, a ośmiu z nich wskazuje, że w ten sposób unika się zbędnego chaosu.

Negatywne czynniki płynące z przywództwa wizjonerskiego mogą, według sześciu badanych, powodować zahamowanie rozwoju szkoły oraz nauczycieli. Przyczyną może być brak umiejętności pracy w zespole, co zostało podkreślone przez siedmiu badanych. Luka w utrzymaniu obiektywizmu, wskazana przez sześć osób, może być wynikiem niewykorzystywanego potencjału tkwiącego w grupie, co podkreśliło ośmiu $z$ dziewięciu badanych. Taki stan rzeczy według pięciu osób sprzyja konfliktom oraz według trzech badanych sprzyja wypaleniu zawodowemu.

Tabela 4

Analiza przywództwa organicznego - grupa 4

\begin{tabular}{|c|c|c|c|c|}
\hline $\begin{array}{c}\text { Rodzaj } \\
\text { przywództwa }\end{array}$ & \multicolumn{4}{|c|}{ Aspekt } \\
\hline \multirow{9}{*}{ 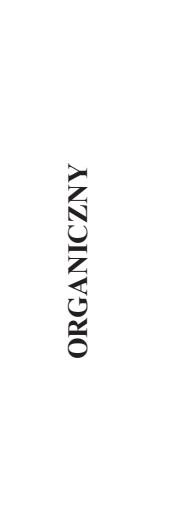 } & pozytywny & $\mathbf{n}$ & negatywny & $\mathbf{n}$ \\
\hline & $\begin{array}{l}\text { zaangażowanie wszystkich } \\
\text { członków grupy }\end{array}$ & 9 & opóźnianie działań & 9 \\
\hline & $\begin{array}{l}\text { wykorzystanie kompetencji } \\
\text { predyspozycji indywidu- } \\
\text { alnych }\end{array}$ & 7 & $\begin{array}{l}\text { rozpraszanie } \\
\text { odpowiedzialności }\end{array}$ & 9 \\
\hline & kreatywność & 6 & & \multirow{6}{*}{-} \\
\hline & synergia & 8 & & \\
\hline & elastyczność zespołu & 5 & & \\
\hline & wsparcie & 8 & & \\
\hline & akceptacja różnorodności & 7 & & \\
\hline & delegowanie uprawnień & 9 & & \\
\hline
\end{tabular}

Źródło: opracowanie własne.

W przeważającej większości respondenci wskazali pozytywne cechy przywództwa organicznego. Przede wszystkim według wszystkich badanych w życie i funkcjonowanie szkoły włączani są członkowie grupy, przez co wykorzystywany jest, według siedmiu z dziewięciu badanych, potencjał zespołu. Według wszystkich respondentów delegowanie uprawnień oraz według ośmiu badanych szeroko udzielane wsparcie sprzyjają kreatywności i elastyczności zespołu. Siedmiu respondentów uważa, że w przywództwie organicznym wszechstronnie akceptowana jest różnorodność, co według ośmiu osób sprzyja synergii budowanej w zespole.

Jako negatywne aspekty przywództwa organicznego wszyscy badani wskazali opóźnienie działalności oraz rozproszenie odpowiedzialności. 


\section{Wnioski}

Specyfika przywództwa edukacyjnego jest złożona. Z badań prowadzonych przez Grzegorza Mazurkiewicza w 2012 roku, prezentujących opinie dyrektorów szkół różnego typu, wynika, że powszechnie akceptowany jest styl przywództwa klasycznego, w którym kontrola i nadzór są pierwszorzędne, co znalazło potwierdzenie w przedstawionej analizie. Nie ma możliwości dokonywania zmian i dostosowywania szkół do rozwiązywania współczesnych problemów, dopóki dyrektorzy placówek oświatowych nie będą koncentrowali się na procesach włączania w działania przywódcze wszystkich członków organizacji. Prowadzony dialog powinien toczyć się w relacjach interpersonalnych nastawionych na ciągłe zmiany zachodzące na poziomie indywidualnym, zespołowym i organizacyjnym [Dorczak, 2013].

Poszukiwanie własnego modelu przywództwa i bycie liderem nie jest łatwe. Dotyczy to wzlotów i upadków. Pojawiający się lęk należy przemieniać w wiarę i budować prawdziwą wspólnotę. Przywództwo powinno być najpierw wyborem, a później zobowiązaniem [Harkins, Swift, 2010]. W sferze edukacji pamiętać należy o budowaniu atmosfery społeczno-moralnej, która wydaje się dawać podstawy do wzorcowego tworzenia kultury organizacji [Dorczak, 2009].

Dyrektorzy szkół, którzy kładą nacisk na przywództwo partycypacyjne, mają większe szanse na zmotywowanie grona pedagogicznego do działania w kierunku tworzenia wspólnych celów, strategii rozwoju szkoły oraz bycia zaangażowanym w codziennej pracy na rzecz innych [Madalińska-Michalak, Kołodziejczyk, 2015; Dorczak, Hesse, 2016a]. Ważne jest, aby wykorzystywać zbiorową inteligencję, która będzie wynikiem współpracy wszystkich osób tworzących społeczność szkolną [Senge, 2012].

\section{Bibliografia}

Avery G.C. (2009), Przywództwo w organizacji. Paradygmaty i studia przypadków, tłum. G. Dąbkowski, Polskie Wydawnictwo Ekonomiczne, Warszawa.

Blanchard K. (2016), Przywództwo wyższego stopnia, tłum. B. Sałbut, Wydawnictwo Naukowe PWN, Warszawa.

Collins J. (2001), Level 5 Leadership: The Triumph of Humility and Fierce Resolve, „Harvard Business Review", 79, 1, 67-76.

Dorczak R. (2009), Zarządzanie w edukacji-wyzwania i możliwości, „Zarządzanie Publiczne", 2(6), 11-25.

Dorczak R. (2013), Dyrektor szkoły jako przywódca edukacyjny - próba określenia kompetencji kluczowych [w:] G. Mazurkiewicz (red.), Przywództwo i zmiana w edukacji. Ewaluacja jako mechanizm doskonalenia (s. 75-88), Wydawnictwo Uniwersytetu Jagiellońskiego, Kraków.

Dorczak R. (2015a), Przez Ateny czy Spartę - w poszukiwaniu właściwej drogi dla przywództwa edukacyjnego [w:] G. Mazurkiewicz (red.), Przywództwo edukacyjne. Zaproszenie do dialogu (s. 37-52), Wydawnictwo Uniwersytetu Jagiellońskiego, Kraków. 
Dorczak R. (2015b), Zarządzanie i przywództwo w edukacji - gdzie jesteśmy i dokąd zmierzamy [w:] R. Dorczak, G. Mazurkiewicz (red.), Przywództwo edukacyjne. Próba zmiany (s. 11-28), Wydawnictwo Uniwersytetu Jagiellońskiego, Kraków.

Dorczak R., Hesse-Gawęda A. (2016a), Styles of Leadership of Headteachers of Polish Schools of Different Types [w:] $10^{\text {th }}$ International Technology, Education and Development Conference (s. 450-454), INTED Academy 2016, Spain.

Dorczak R., Hesse-Gawęda A. (2016b), Kompetencje edukacyjne i kulturowe w przywództwie edukacyjnym [w:] R. Dorczak, Wybrane aspekty zarządzania i przywództwa edukacyjnego (s. 63-74), Instytut Spraw Publicznych UJ, Kraków.

Harkins P., Swift P. (2010), W poszukiwaniu modelu przywództwa, tłum. W. Biliński, Oficyna a Wolters Kluwer business, Warszawa.

Madalińska-Michalak J. (2007), Istota i modele przywództwa szkolnego [w:] J. Madalińska-Michalak (red.), Przywództwo w szkole (s. 63-80), Wydawnictwo Impuls, Kraków.

Madalińska-Michalak J., Kołodziejczyk J. (2015), Przywództwo i zarządzanie w szkole. W poszukiwaniu równowagi [w:] G. Mazurkiewicz (red.), Przywództwo edukacyjne. Zaproszenie do dialogu (s. 121-134), Wydawnictwo Uniwersytetu Jagiellońskiego, Kraków.

Mazurkiewicz G. (2011), Przywództwo edukacyjne. Odpowiedzialne zarzadzanie edukacja wobec wyzwań współczesności, Wydawnictwo Uniwersytetu Jagiellońskiego, Kraków.

Mazurkiewicz G. (2012), Edukacja i przywództwo. Modele mentalne jako bariery rozwoju, Wydawnictwo Uniwersytetu Jagiellońskiego, Kraków.

Mazurkiewicz G. (2015), Władcy umystów - wielogłos w procesie podejmowania decyzji o edukacji. Tworzenie, wspólnota, zarzadzanie [w:] B. Nierenberg, R. Batko, Ł. Sułkowski (red.), Zarzadzanie humanistyczne (s. 175-188), Wydawnictwo Uniwersytetu Jagiellońskiego, Kraków.

Mintzberg H. (1998), Cover Leadership: Notes on Managing Professionals, „Harvard Business Review", 76, 6, 140-147.

Senge P. (2012), Piąta dyscyplina. Teoria i praktyka organizacji uczacych się, tłum. M. Lipa, Oficyna a Wolters Kluwer business, Warszawa.

Stoner J., Wankel Ch. (1996), Kierowanie, tłum. A. Ehrlich, Polskie Wydawnictwo Ekonomiczne, Warszawa.

Ustawa z dnia 7 września 1991 r. o systemie oświaty [UoSO] (Dz.U. z 2016 r., poz. 1943, 1954, 1985 i 2169, oraz z 2017 r., poz. 60).

Yukl G. (2014), Leadership in Organizations, Edition Eighth, PEARSON, India. 